Dokuz Eylül Üniversitesi-Mühendislik Fakültesi

Fen ve Mühendislik Dergisi

Cilt 19, Sayı 57, Eylül 2017
Dokuz Eylul University-Faculty of Engineering Journal of Science and Engineering Volume 19, Issue 57, September 2017

DOI: $10.21205 /$ deufmd.2017195782

\title{
Improvement of Stability of Hydrogen Peroxide using Ethylene Glycol
}

\section{Ersin Yener YAZICI ${ }^{*}$}

1'Karadeniz Teknik Üniversitesi, Mühendislik Fakültesi, Maden Mühendisliği Bölümü, 61080, Trabzon

(Alınış / Received: 13.03.2017, Kabul / Accepted: 13.06.2017, Online Yayınlanma / Published Online: 20.09.2017)

Keywords

Hydrogen peroxide, Ethylene glycol, Citric acid, Stability, Copper, Ergun's test
Abstract: Owing to its high oxidising power and environmentally friendly nature, hydrogen peroxide $\left(\mathrm{H}_{2} \mathrm{O}_{2}\right)$ is commonly used in environmental and hydrometallurgical applications such as treatment of cyanidation effluents and leaching of metals from ores/concentrates/waste materials. However, $\mathrm{H}_{2} \mathrm{O}_{2}$ rapidly undergoes catalytic decomposition particularly in the presence of metal ions such as copper. The aim of this study is to investigate the influence of certain additives on the improvement of stability of $\mathrm{H}_{2} \mathrm{O}_{2}$. The influence of addition of ethylene glycol (2.5-20 mL/L) and citric acid (4.8-80 mM) on the stability of $\mathrm{H}_{2} \mathrm{O}_{2}$ in the absence/presence of copper was tested. The time-dependent data were statistically analysed using Ergun's test. No effect of ethylene glycol was observed on the stability of $\mathrm{H}_{2} \mathrm{O}_{2}$ in the absence of $\mathrm{Cu}$ while a substantial improvement (up to $33 \%$ ) was noted in its presence. The addition of citric acid in the presence of copper negatively influenced the stability of $\mathrm{H}_{2} \mathrm{O}_{2}$.

\section{Hidrojen Peroksitin Kararlılığının Etilen Glikol Kullanılarak İyileştirilmesi ve Ergun Testi ile Verilerin İstatistiksel Değerlendirmesi}

\begin{abstract}
Anahtar
Kelimeler

Özet: Yüksek oksitleyici özelliği ve çevre dostu bir reaktif olması

Hidrojen peroksit, nedeniyle, hidrojen peroksit $\left(\mathrm{H}_{2} \mathrm{O}_{2}\right)$ siyanürlü atık çözeltilerin rehabilitasyonu ve metallerin cevher/konsantre/atıklardan liçi Etilen glikol, gibi çevresel ve hidrometalurjik uygulamalarda yaygın olarak Sitrik asit, kullanılmaktadır. Ancak $\mathrm{H}_{2} \mathrm{O}_{2}$, özellikle bakır gibi metal iyonlarının varlığında katalitik bozunmaya uğramaktadır. $\mathrm{Bu}$ çalışmanın Kararlılık, Bakır, Ergun testi amacı, belirli katkı maddelerinin $\mathrm{H}_{2} \mathrm{O}_{2}$ kararlığına etkisinin araştırılmasıdır. Etilen glikol (2,5-20 mL/L) ve sitrik asit (4,8-80 $\mathrm{mM}$ ) ilavesinin $\mathrm{H}_{2} \mathrm{O}_{2}$ kararlılı̆̆na etkisi bakır yokluğunda/ varlığında test edilmiştir. Zamana bağlı verilerin istatistiksel analizinde Ergun testi kullanılmıştır. Bakır yokluğunda etilen glikolün $\mathrm{H}_{2} \mathrm{O}_{2}$ kararlılığına bir etkisi gözlenmemesine karşın bakır varlığında \%33'e varan iyileștirme sağlanmıștır. Sitrik asit ilavesi bakır varlığında $\mathrm{H}_{2} \mathrm{O}_{2}$ kararlığını olumsuz etkilemiştir.
\end{abstract}




\section{Introduction}

Hydrogen peroxide $\left(\mathrm{H}_{2} \mathrm{O}_{2}\right)$ is a versatile and simple inorganic compound utilised extensively in various fields owing to its high oxidising power $\left(\mathrm{E}^{0}=+1.78 \mathrm{~V}\right)$ and environmentally benign nature [1]. Hydrogen peroxide decomposes to nontoxic products (i.e. oxygen and water), which renders it "green reagent" (Eq. 1) $[1,2]$. The fields of applications of hydrogen peroxide are presented in Figure 1. Hydrogen peroxide is preferred in several environmental applications e.g. removal/oxidation of toxic inorganic substances (e.g. sulphide ( $\mathrm{S}^{2-}$ ), nitrite) and organic compounds in effluents including advanced oxidation processes (UV/ $\mathrm{H}_{2} \mathrm{O}_{2}, \quad \mathrm{UV} / \mathrm{H}_{2} \mathrm{O}_{2} / \mathrm{O}_{3}, \quad \mathrm{H}_{2} \mathrm{O}_{2} / \mathrm{O}_{3}$ or Fenton's process $\left(\mathrm{H}_{2} \mathrm{O}_{2} / \mathrm{Fe}^{2+}\right)$ as well as treatment of cyanide leaching effluents, which contain free cyanide and/or metalcyanide complexes (i.e. WAD cyanide) (Figure 1). It can be also utilised in certain hydrometallurgical applications as an oxidant or source of oxygen in the extraction of gold/silver from ores (though excess use may increase consumption of cyanide) $\left[\begin{array}{ll}1, & 3\end{array}\right]$, precipitation of uranium or plutanoium in peroxide form from pregnant leach solutions (PLS) [2,4] and sulphate/chloride leaching of copper from its ores/concentrates $[5,6]$ and waste materials such as waste electrical and electronic equipments (WEEE or ewaste) [7-10] (Figure 1). Other applications are synthesis of fine chemicals, cosmetics, pharmaceutical products, bleaching of paper, pulp and textile and chemical purification of organic compounds (Figure 1).

$$
\begin{aligned}
& 2 \mathrm{H}_{2} \mathrm{O}_{2(a q)} \rightarrow 2 \mathrm{H}_{2} \mathrm{O}_{(a q)}+\mathrm{O}_{2(g)} \\
& \left(\Delta G^{0}=-206 \mathrm{~kJ} \text { at } 25^{\circ} \mathrm{C}\right)
\end{aligned}
$$

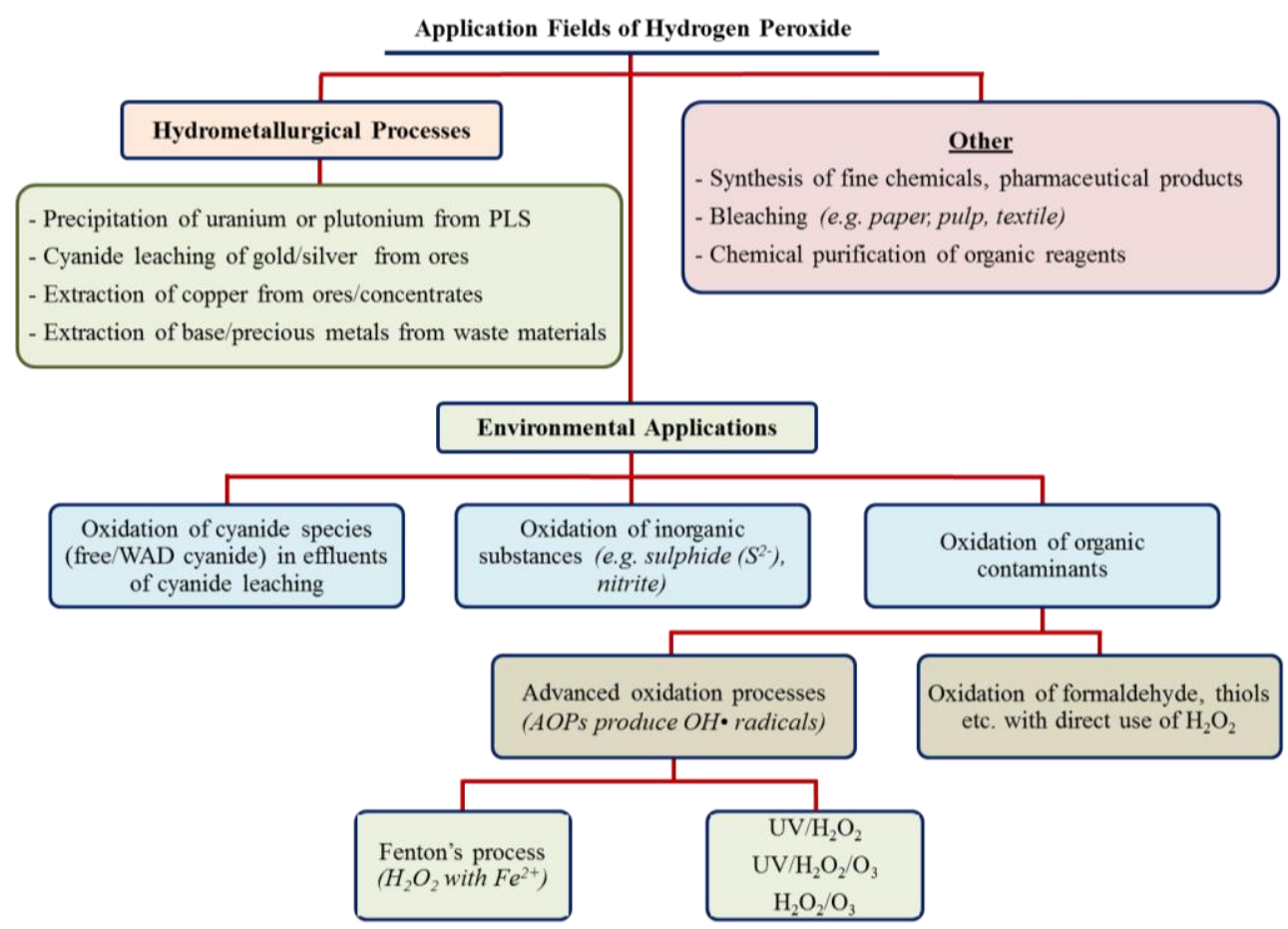

Figure 1. Various applications of hydrogen peroxide [1, 2, 5, 11-13]. 
Although hydrogen peroxide is commonly known as an oxidant, it can also exhibit reductive features usually at acidic solutions [1]. Bas and Yazici [14] demonstrated that addition of $\mathrm{H}_{2} \mathrm{O}_{2}$ into $\mathrm{X}$-ray film processing effluents results in precipitation of silver from thiosulphate media as metallic silver (with reducing effect of $\mathrm{H}_{2} \mathrm{O}_{2}$ ) and silver sulphide with the latter more dominant phase.

Besides its technical and environmental advantages, the most severe detraction to hydrogen peroxide is its prohibitively high consumption in the presence of metal ions e.g. $\mathrm{Cu}^{2+}, \mathrm{Fe}^{3+}, \mathrm{Fe}^{2+}, \mathrm{Mn}$, and $\mathrm{Cr}^{2+}$. Copper, which is one of the main impurity ion present in effluents, is reduced to cuprous state through reaction with hydrogen peroxide (Eq. 2) [12]. Notwithstanding this, the presence of sulphur ( $\left.\mathrm{S}^{2-}\right)$ and thiocyanate ( $\mathrm{SCN}^{-}$) ions as well as solids have adverse effect on stability of $\mathrm{H}_{2} \mathrm{O}_{2}$. High $\mathrm{pH}$ and temperature also facilitate the decomposition of hydrogen peroxide $[1,7,12,15,16]$. To overcome high consumption of $\mathrm{H}_{2} \mathrm{O}_{2}$ through its catalytic decomposition in the presence of metal ions, addition of inorganic/organic reagents have been tested to reduce the reactivity of metal ions towards $\mathrm{H}_{2} \mathrm{O}_{2}$ by complexation/chelation of metals [1720]. However, almost all the earlier studies appear to focus mainly on extending the shell life of concentrated acidic (stock) solutions of hydrogen peroxide $\left(25-90 \% \mathrm{w} / \mathrm{w} \mathrm{H}_{2} \mathrm{O}_{2}\right)$. To the author's knowledge, only a few studies $[14,26]$ have been reported on practical use of additives on improvement of stability of hydrogen peroxide. Bas et al. [14] investigated the effect of ethylene glycol on recovery of silver from X-ray film effluents with $\mathrm{H}_{2} \mathrm{O}_{2}$. Mahajan and Misra [26] studied the influence of ethylene glycol on extraction of copper from chalcopyrite mineral using $\mathrm{H}_{2} \mathrm{SO}_{4}+\mathrm{H}_{2} \mathrm{O}_{2}$ leaching

$$
\begin{gathered}
2 \mathrm{Cu}^{2+}+\mathrm{H}_{2} \mathrm{O}_{2}+2 \mathrm{OH}^{-} \rightarrow \\
2 \mathrm{Cu}^{+}+\mathrm{O}_{2}+2 \mathrm{H}_{2} \mathrm{O}
\end{gathered}
$$

This study investigated the influence of addition of ethylene glycol (2.5-20 mL/L) and citric acid (4.8-80 $\mathrm{mM})$ for stabilisation of $\mathrm{H}_{2} \mathrm{O}_{2}$ under different experimental conditions of $\mathrm{pH}(2-4)$ and temperature $\left(20-80^{\circ} \mathrm{C}\right)$ in the absence and presence of copper $(5 \mathrm{~g} / \mathrm{L} \mathrm{Cu}$ ) over 3 h. Ergun's test was adopted in the study to test statistical significance of the timedependent data.

\section{Material and Method}

\subsection{Experimental set-up and procedure}

All the tests were performed in 250-mL jacketed glass reactors (inner dia: 6.5 $\mathrm{cm}$ ) equipped with two baffles. Reactors were connected to a temperature controlled water circulator (Polyscience). Reactor contents were agitated by a multi magnetic stirrer (Thermo Scientific Variomag) using PTFE-coated magnetic bars (dia.: $3 \mathrm{~cm}$ ) at $350 \mathrm{rpm}$. The top of reactors were kept covered with lids over the test period. Hydrogen peroxide solution (35\% w/w $\mathrm{H}_{2} \mathrm{O}_{2}$, Merck) and a stock solution of copper sulphate (200 $\mathrm{g} / \mathrm{L} \mathrm{CuSO}_{4} .5 \mathrm{H}_{2} \mathrm{O}$ ) were used to prepare the solutions in a final volume of $200 \mathrm{~mL}$. Hydrogen peroxide was introduced into the solution after maintaining the required temperature in order to inhibit its early decomposition prior to start-up of the tests. Initial concentration of $\mathrm{H}_{2} \mathrm{O}_{2}$ was set at $0.5 \mathrm{M}$ in all experiments. Two different organic additives; namely, ethylene glycol and citric acid (Figure 2) were used to test their influence on the stabilisation of $\mathrm{H}_{2} \mathrm{O}_{2}$. Ethylene glycol $\left(\geq 99 \% \quad \mathrm{C}_{2} \mathrm{H}_{6} \mathrm{O}_{2}\right.$ ) was added in required amounts to maintain dosages of $2.5-20$ $\mathrm{mL} / \mathrm{L}$. Citric acid monohydrate $(\geq 99.0 \%$ $\mathrm{C}_{6} \mathrm{H}_{8} \mathrm{O}_{7} . \mathrm{H}_{2} \mathrm{O}$ ) was used for preparation of a stock solution from which test 
solutions were prepared at the required concencentrations of $4.8-80 \mathrm{mM}$ corresponding to $[\mathrm{Cit}] /[\mathrm{Cu}]$ ratios (molar) of $0.06-1 \mathrm{mM}$. pH of solutions was adjusted using concentrated sulphuric acid $\left(96 \% \mathrm{H}_{2} \mathrm{SO}_{4}\right)$ or $4 \mathrm{M} \mathrm{NaOH}$.
All the solutions were prepared using deionised-distilled water. During the period of $180 \mathrm{~min}$., samples were taken at predetermined intervals to analyse initial/residual $\mathrm{H}_{2} \mathrm{O}_{2}$ with iodometric titration [21].<smiles>OCCO</smiles><smiles>CC(=O)C(O)C(C(=O)O)C(=O)O</smiles>

Figure 1. Molecular structure of ethylene glycol (left) [22] and citric acid (right) [23]

\subsection{Statistical analysis of data using Ergun's test}

Conventional statistical methods do not allow evaluation of time-dependent data e.g. decomposition $v s$ time. Recent studies indicated that Ergun's test, which is essentially One-way Analysis of Variance (ANOVA) for gradients/slopes, is a practical tool for statistical analysis of time-dependent data. Ergun's test was used in this study for eradication of time dependency of data and interpretation of the influence of ethylene glycol and citric acid on the stability of $\mathrm{H}_{2} \mathrm{O}_{2}$ under different experimental conditions (pH (2-4), temperature $\left(20-80^{\circ} \mathrm{C}\right)$ and copper $(0-5$ $\mathrm{g} / \mathrm{L} \mathrm{Cu}^{2+}$ ). First-order reaction model were used to collect the rate data, which were then subjected to the statistical evaluation using Ergun's test. Statistical significance of differences i.e. the equality of the gradients (reaction rates) was examined as a Null Hypothesis. Details of Ergun's test can be found elsewhere [24, 25].

\section{Results}

Statistical significance of the addition of ethylene glycol $(2.5-20 \mathrm{~mL} / \mathrm{L})$ and citric acid (4.8-80 mM) on the stability of $\mathrm{H}_{2} \mathrm{O}_{2}$ was determined under different experimental conditions and summary of the results is presented in Table 1 . In the statistical evaluation of the results (Table 1), alpha ( $\alpha$ ) represents the level of significance and the test results are presented as "slightly significant" at $10 \%$, "significant" at 5\%, "highly significant" at $1 \%$ and "extremely significant" at $0.1 \%$ levels. Corresponding plots of fraction of $\mathrm{H}_{2} \mathrm{O}_{2}$ remained (Ratio of final $\mathrm{H}_{2} \mathrm{O}_{2}$ to initial $\mathrm{H}_{2} \mathrm{O}_{2}$ ) vs time are illustrated in Figures 3-10. The rate and extent of decomposition of hydrogen peroxide was rather limited (i.e. $11-17 \%$ over 3 h) in the absence of copper at $\mathrm{pH} \mathrm{2-4}$ and $50^{\circ} \mathrm{C}$ (Figures 3-4). Effect of ethylene glycol was tested under these conditions (Figures 3-4) and no significant influence on stability of $\mathrm{H}_{2} \mathrm{O}_{2}$ was observed. This was also 
corroborated by statistical analysis of data (Table 1). It is relevant to note that comparison of Figures 3-4 with Figures 5-6 revealed that presence of copper adversely effected $\mathrm{H}_{2} \mathrm{O}_{2}$ stability e.g. remained fractions of $\mathrm{H}_{2} \mathrm{O}_{2}$ over $3 \mathrm{~h}$. were noted as $86 \%$ and $42 \%$ in the absence (Figure 3) and presence of copper (Figure 6), respectively. In copper containing solutions $(5 \mathrm{~g} / \mathrm{L} \mathrm{Cu})$, the addition of ethylene glycol (2.5-20 $\mathrm{mL} / \mathrm{L}$ ) significantly improved (by 27$33 \%$ ) the stability of hydrogen peroxide under less aggresive conditions i.e. at $20-50^{\circ} \mathrm{C}$ (Figures 5 and 6 ). At $20^{\circ} \mathrm{C}$ and $\mathrm{pH} 4$, the fraction of $\mathrm{H}_{2} \mathrm{O}_{2}$ remained in solution decreased to $27 \%$ over $3 \mathrm{~h}$. (Figure 4). However, the introduction of ethylene glycol into the medium at a dosage of $20 \mathrm{~mL} / \mathrm{L}$ substantially improved the stability of $\mathrm{H}_{2} \mathrm{O}_{2}$ (i.e. $53 \%$ of $\mathrm{H}_{2} \mathrm{O}_{2}$ remained in solution compared with $27 \%$ in the absence of ethylene glycol) over the same period of $3 \mathrm{~h}$. (Figure 5).

Table 1. Statistical analysis of the experimental data using Ergun's test

\begin{tabular}{|c|c|c|c|}
\hline Effect of Ethylene Glycol & P-value & Alpha $(\alpha)$ & Significance \\
\hline \multicolumn{4}{|l|}{ In the absence of copper } \\
\hline \multicolumn{4}{|l|}{$\mathrm{pH} 2$ and $50^{\circ} \mathrm{C}$} \\
\hline 0 vs $20 \mathrm{~mL} / \mathrm{L}$ Glycol & 0.1546 & $0.1(10 \%)$ & Not significant \\
\hline \multicolumn{4}{|l|}{$\mathrm{pH} 4$ and $50^{\circ} \mathrm{C}$} \\
\hline o vs $20 \mathrm{~mL} / \mathrm{L}$ Glycol & 0.1428 & $0.1(10 \%)$ & Not significant \\
\hline \multicolumn{4}{|l|}{ In the presence of $5 \mathrm{~g} / \mathrm{L} \mathrm{Cu}$} \\
\hline \multicolumn{4}{|l|}{$\mathrm{pH} 4$ and $20^{\circ} \mathrm{C}$} \\
\hline O vs $20 \mathrm{~mL} / \mathrm{L}$ Glycol & 0.0000 & $0.001(0.1 \%)$ & Ext. significant \\
\hline \multicolumn{4}{|l|}{$\mathrm{pH} 2$ and $50^{\circ} \mathrm{C}$} \\
\hline 0-20 mL/L Glycol & 0.0000 & $0.001(0.1 \%)$ & Ext. significant \\
\hline 0 vs $2.5 \mathrm{~mL} / \mathrm{L}$ Glycol & 0.0000 & $0.001(0.1 \%)$ & Ext. significant \\
\hline 0 vs $20 \mathrm{~mL} / \mathrm{L}$ Glycol & 0.0000 & $0.001(0.1 \%)$ & Ext. significant \\
\hline 2.5 vs $20 \mathrm{~mL} / \mathrm{L}$ Glycol & 0.1468 & $0.1(10 \%)$ & Not significant \\
\hline \multicolumn{4}{|l|}{$\mathrm{pH} 2$ and $80^{\circ} \mathrm{C}$} \\
\hline 0-20 mL/L Glycol & 0.7868 & $0.1(10 \%)$ & Not significant \\
\hline Effect of Citric acid & P-value & Alpha ( $\alpha)$ & Significance \\
\hline \multicolumn{4}{|c|}{ In the absence of copper $\left(\mathrm{pH} 2\right.$ and $\left.50^{\circ} \mathrm{C}\right)$} \\
\hline 0-80 mM Citric Acid & 0.1088 & $0.1(10 \%)$ & Not significant \\
\hline \multicolumn{4}{|c|}{ In the presence of $5 \mathrm{~g} / \mathrm{L} \mathrm{Cu}\left(\mathrm{pH} 2\right.$ and $\left.50^{\circ} \mathrm{C}\right)$} \\
\hline 0-80 mM Citric Acid & 0.0000 & $0.001(0.1 \%)$ & Ext. significant \\
\hline 0 vs 4.8 mM Citric Acid & 0.0002 & $0.001(0.1 \%)$ & Ext. significant \\
\hline
\end{tabular}

The contribution of ethylene glycol to the stability of $\mathrm{H}_{2} \mathrm{O}_{2}$ was also confirmed by Ergun's test (Table 1). Similar results were obtained at $50^{\circ} \mathrm{C}$ and $\mathrm{pH} 2$ in that, despite low residual fraction of $\mathrm{H}_{2} \mathrm{O}_{2}$ by
$\% 42$ without ethylene glycol over $3 \mathrm{~h}$., the addition of glycol even at $2.5 \mathrm{~mL} / \mathrm{L}$ resulted in a higher residual fraction of 73\% (Figure 6, Table 1). 
E.Y. Yazıcı / Improvement of Stability of Hydrogen Peroxide using Ethylene Glycol

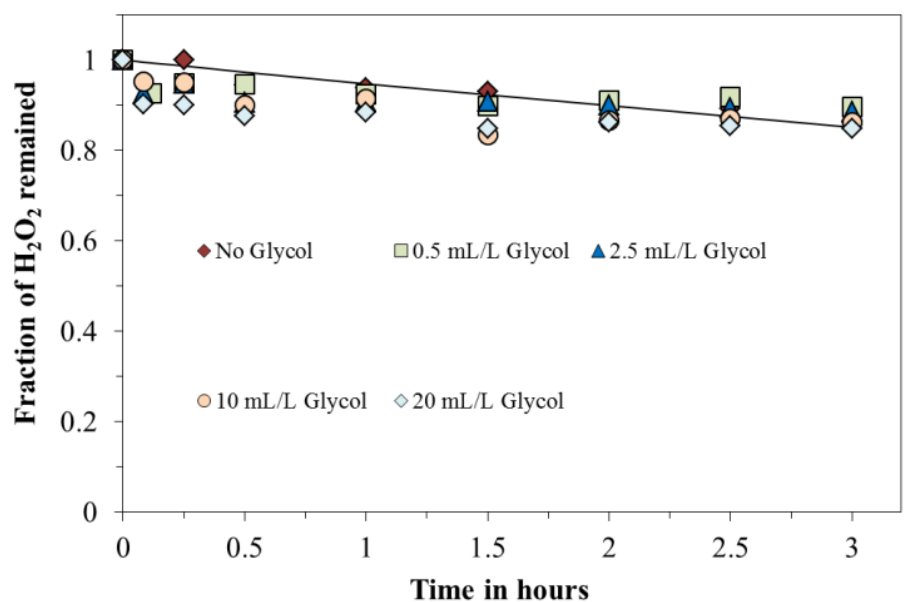

Figure 3. Stability of $\mathrm{H}_{2} \mathrm{O}_{2}$ with/without ethylene glycol in the absence of $\mathrm{Cu}$ at $50^{\circ} \mathrm{C}$ and $\mathrm{pH} 2$

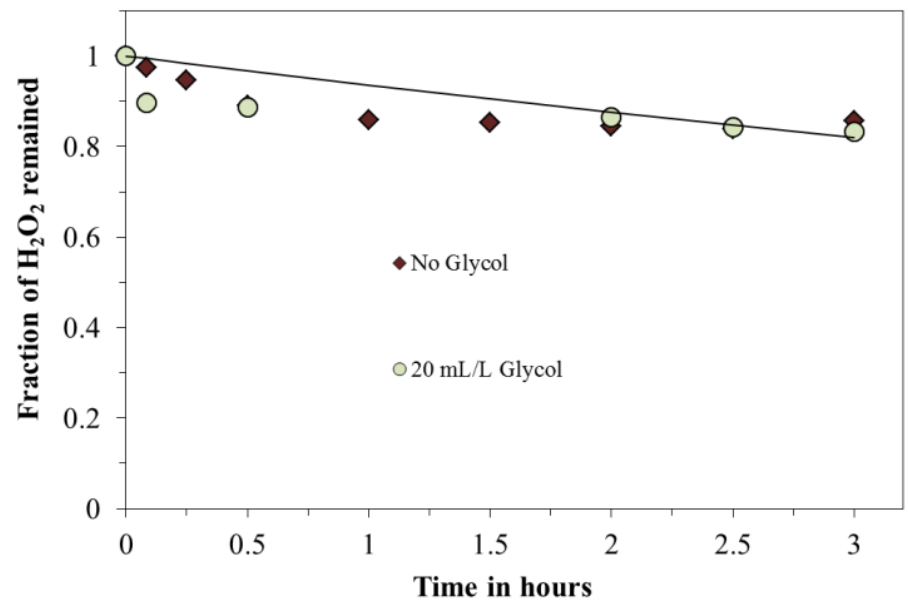

Figure 4. Stability of $\mathrm{H}_{2} \mathrm{O}_{2}$ with/without ethylene glycol in the absence of $\mathrm{Cu}$ at $50^{\circ} \mathrm{C}$ and $\mathrm{pH} 4$

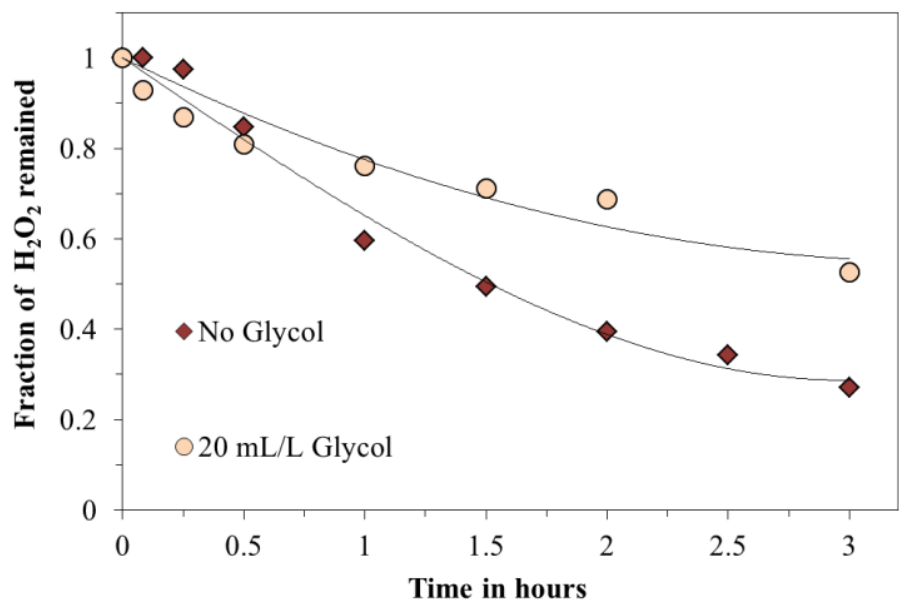

Figure 5. Stability of $\mathrm{H}_{2} \mathrm{O}_{2}$ with/without glycol in the presence of $5 \mathrm{~g} / \mathrm{L} \mathrm{Cu}$ at $20^{\circ} \mathrm{C}$ and $\mathrm{pH} 4$ 


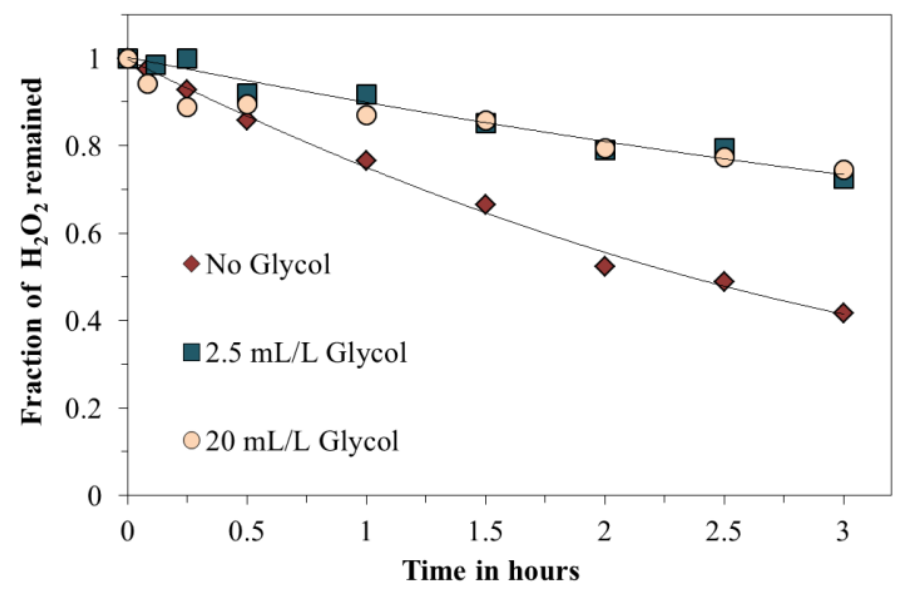

Figure 6. Stability of $\mathrm{H}_{2} \mathrm{O}_{2}$ with/without glycol in the presence of $5 \mathrm{~g} / \mathrm{L} \mathrm{Cu}$ at $50^{\circ} \mathrm{C}$ and pH 2

Increasing the dosage of ethylene glycol from 2.5 to $20 \mathrm{~mL} / \mathrm{L}$ did not provide a further improvement (Figure 6). This was also consistent with the results of statistical assessment of data using Ergun's test (Table 1).

Figures 7-8 show the decomposition trend of $\mathrm{H}_{2} \mathrm{O}_{2}$ with/without ethylene glycol in the presence of copper $(5 \mathrm{~g} / \mathrm{L}$
$\mathrm{Cu}$ ) under more aggressive conditions (i.e. at $80^{\circ} \mathrm{C}$ ). Compared with the results obtained at $20-50^{\circ} \mathrm{C}$ (Figures 5-6), a sharp and rapid reduction in the concentration of $\mathrm{H}_{2} \mathrm{O}_{2}$ was observed at $80^{\circ} \mathrm{C}$ over an initial period of only $5 \mathrm{~min}$. (Figures 7-8). This indicated the significance of temperature-dependent decomposition of $\mathrm{H}_{2} \mathrm{O}_{2}$.

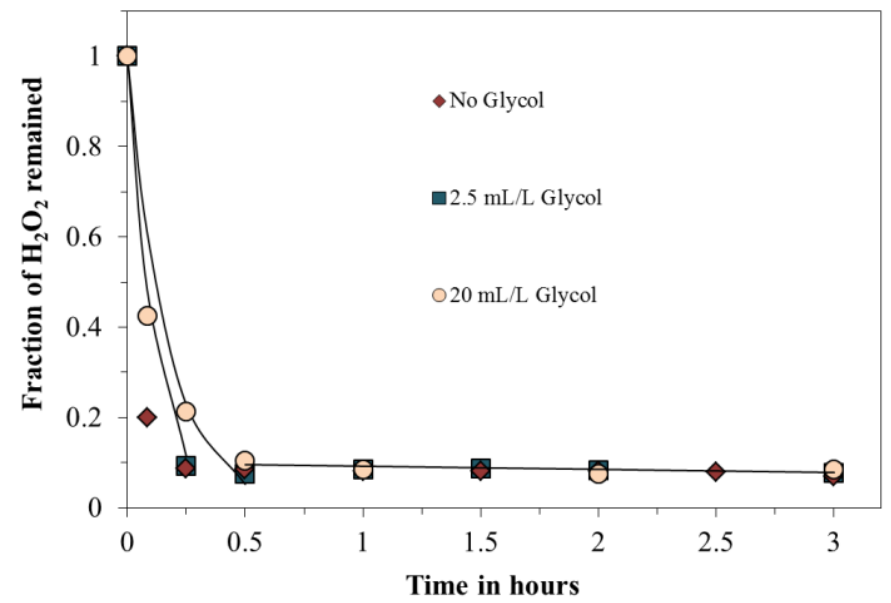

Figure 7. Stability of $\mathrm{H}_{2} \mathrm{O}_{2}$ with/without glycol in the presence of $5 \mathrm{~g} / \mathrm{L} \mathrm{Cu}$ at $80^{\circ} \mathrm{C}$ and pH 2 


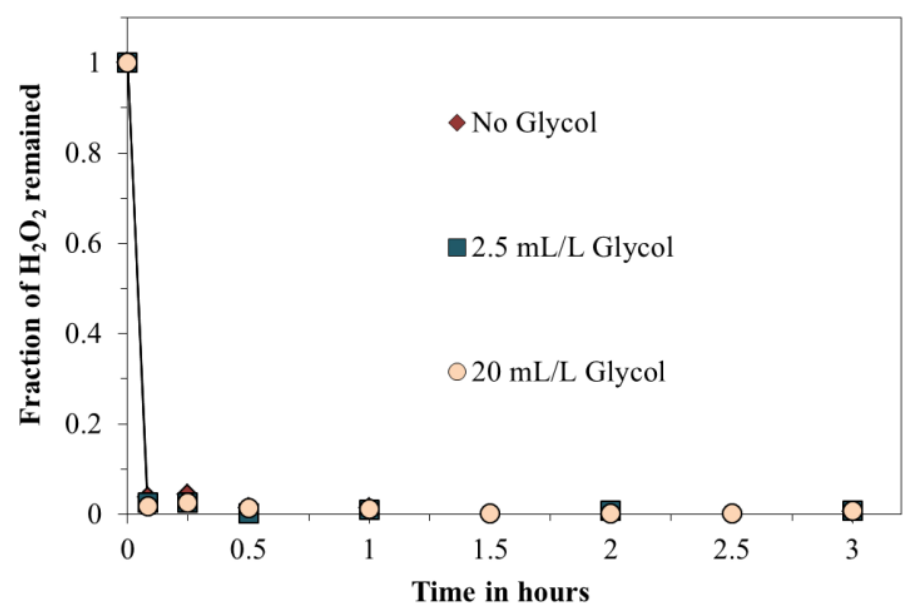

Figure 8. Stability of $\mathrm{H}_{2} \mathrm{O}_{2}$ with/without glycol in the presence of $5 \mathrm{~g} / \mathrm{L} \mathrm{Cu}$ at $80^{\circ} \mathrm{C}$ and pH 4

Only $20 \%$ of $\mathrm{H}_{2} \mathrm{O}_{2}$ was remained in solution at an initial period of $5 \mathrm{~min}$. at $80^{\circ} \mathrm{C}$ and $\mathrm{pH} 2$ (Figure 7). Increasing the $\mathrm{pH}$ further to 4 led to more severe impact on the stability of $\mathrm{H}_{2} \mathrm{O}_{2}$ with only $4 \%$ of $\mathrm{H}_{2} \mathrm{O}_{2}$ that remained in solution at 5 min. (Figure 8). At $80^{\circ} \mathrm{C}$ and $\mathrm{pH} \mathrm{2,}$ addition of ethylene glycol even at the highest dosage of $20 \mathrm{~mL} / \mathrm{L}$ produced an ameliorating effect on the decomposition of $\mathrm{H}_{2} \mathrm{O}_{2}$ only over the initial periods of $\leq 30 \mathrm{~min}$. e.g. the remained fraction of $\mathrm{H}_{2} \mathrm{O}_{2}$ increased from $20 \%$ to $43 \%$ at $5 \mathrm{~min}$. (Figure 7 ). However, statistical test did not identify a significant effect considering the initial reaction period of $15 \mathrm{~min}$. (Table 1 ).
Increasing the $\mathrm{pH}$ from 2 to 4 under the same conditions of $80^{\circ} \mathrm{C}$ and $5 \mathrm{~g} / \mathrm{L} \mathrm{Cu}$ (Figure 8) resulted in complete decomposition of $\mathrm{H}_{2} \mathrm{O}_{2}$ even at the highest dosage (i.e. $20 \mathrm{~mL} / \mathrm{L}$ ).

The influence of citric acid on the stability of $\mathrm{H}_{2} \mathrm{O}_{2}$ was also tested in the absence and presence of copper at $50^{\circ} \mathrm{C}$ and pH 2 (Figures 9-10). Citric acid is a weak organic acid which dissociates in water according to the Eqs. 3-5 [27]. It was observed that citric acid did not influence the stability of $\mathrm{H}_{2} \mathrm{O}_{2}$ in the absence of copper (Figure 9, Table 1) as also noted for ethylene glycol (Figures 3-4).

$$
\begin{array}{ll}
\mathrm{C}_{6} \mathrm{H}_{8} \mathrm{O}_{7(s)}+\mathrm{H}_{2} \mathrm{O} \rightarrow \mathrm{H}_{3} \mathrm{O}^{+}+\mathrm{C}_{6} \mathrm{H}_{7} \mathrm{O}_{7(a q)}^{-} & \left(\mathrm{pK}_{1}=3.128\right) \\
\mathrm{C}_{6} \mathrm{H}_{7} \mathrm{O}_{7(a q)}^{-}+\mathrm{H}_{2} \mathrm{O} \rightarrow \mathrm{H}_{3} \mathrm{O}^{+}+\mathrm{C}_{6} \mathrm{H}_{6} \mathrm{O}_{7(a q)}^{2-} & \left(\mathrm{pK}_{2}=4.761\right) \\
\mathrm{C}_{6} \mathrm{H}_{6} \mathrm{O}_{7(a q)}^{2-}+\mathrm{H}_{2} \mathrm{O} \rightarrow \mathrm{H}_{3} \mathrm{O}^{+}+\mathrm{C}_{6} \mathrm{H}_{5} \mathrm{O}_{7(a q)}^{3-} & \left(\mathrm{pK}_{3}=6.396\right)
\end{array}
$$




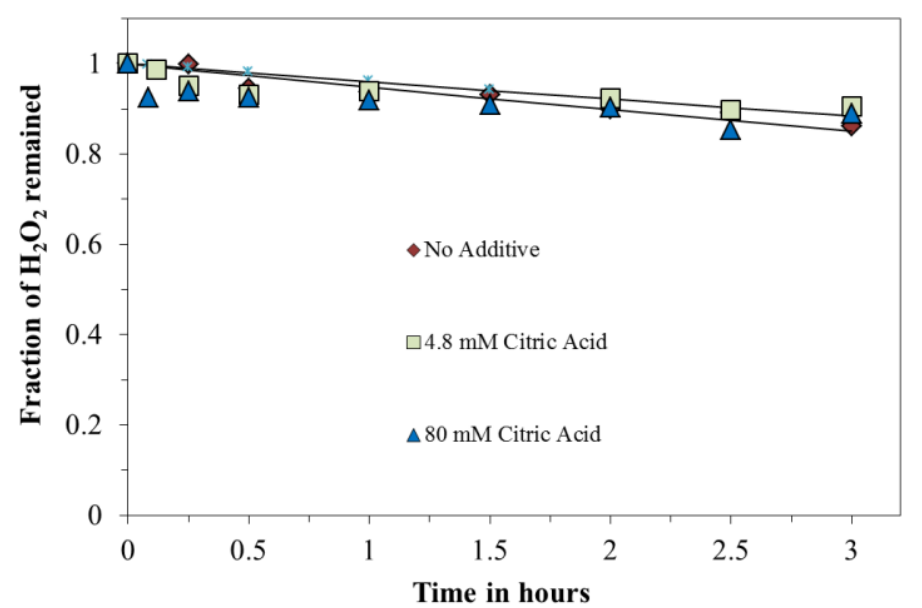

Figure 9. Stability of $\mathrm{H}_{2} \mathrm{O}_{2}$ with/without citric acid in the absence of $\mathrm{Cu}$ at $50^{\circ} \mathrm{C}$ and $\mathrm{pH} 2$

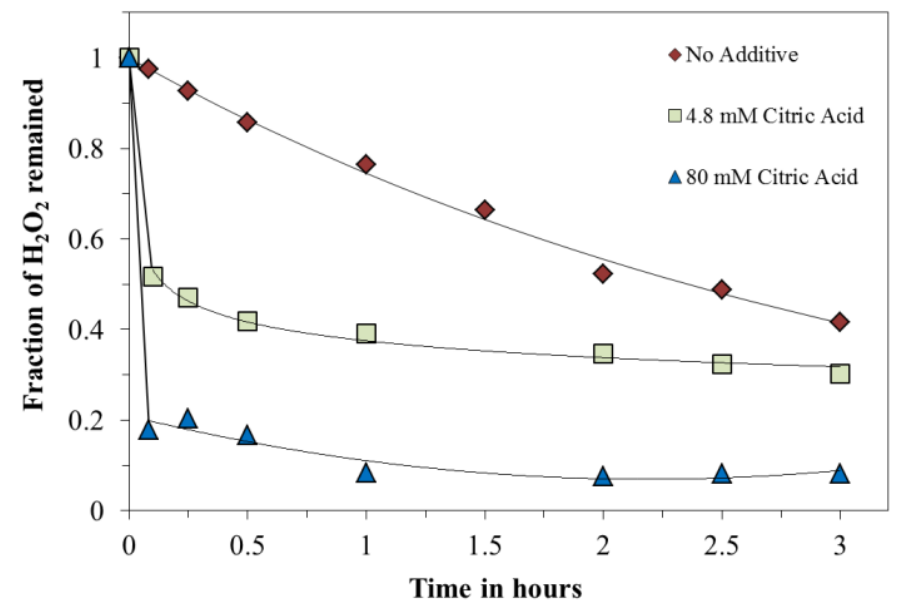

Figure 10. Stability of $\mathrm{H}_{2} \mathrm{O}_{2}$ with/without citric acid in the presence of $5 \mathrm{~g} / \mathrm{L} \mathrm{Cu}$ at $50^{\circ} \mathrm{C}, \mathrm{pH} 2$

To exploit the complexing ability of citric acid for $\mathrm{Cu}(\mathrm{II})(\log K=14.2)$ [28$32]$, citric acid is added in an attempt to improve the stability $\mathrm{H}_{2} \mathrm{O}_{2}$ (Figure 10 ). However, the addition of citric acid was observed to adversely influence the stability of $\mathrm{H}_{2} \mathrm{O}_{2}$ with extensive decomposition of $\mathrm{H}_{2} \mathrm{O}_{2}$. Only $8 \%$ of $\mathrm{H}_{2} \mathrm{O}_{2}$ at $80 \mathrm{mM}$ citric acid was left after $3 \mathrm{~h}$., compared with $42 \%$ in the absence of citric acid. A sharp decrease (by $48 \%$ ) in the concentration of $\mathrm{H}_{2} \mathrm{O}_{2}$ at $4.8 \mathrm{mM}$ citric acid was noted over the initial period of only 5 min. at which $\mathrm{H}_{2} \mathrm{O}_{2}$ was essentially stable (98\%) in the absence of citric acid (Figure 10). Elevating the concentration of citric acid from 4.8 to $80 \mathrm{mM}$ further aggravated the decomposition of $\mathrm{H}_{2} \mathrm{O}_{2}$ (Figure 10). The adverse effect of citric acid on the stability of $\mathrm{H}_{2} \mathrm{O}_{2}$ was also confirmed by the statistical analysis of the data (Table 1). The adverse effect of citric acid in the presence of copper could be attributed to the oxidation of citric acid by $\mathrm{H}_{2} \mathrm{O}_{2}$ (i.e. consumption of $\mathrm{H}_{2} \mathrm{O}_{2}$ ) through catalytic effect of copper. It is pertinent to note that an intense gas release with unpleasent odor was observed during these tests in the presence of copper (particularly at $80 \mathrm{mM}$ citric acid), 
which could be an indicative of degradation of citric acid.

\section{Discussion and Conclusion}

The results have shown that the addition of ethylene glycol as well as citric acid has no effect on the decomposition of $\mathrm{H}_{2} \mathrm{O}_{2}$ in the absence of copper. However, in the presence of copper, ethylene glycol improves the stability of $\mathrm{H}_{2} \mathrm{O}_{2}$ (Figures 5-6). This enhancing effect of ethylene glycol (Figures 5-6) can be attributed to the formation glycol-copper complexes, reducing the reactivity of copper towards $\mathrm{H}_{2} \mathrm{O}_{2}$. In accordance with the current findings (Figures 5-6), previous reports $[14,26]$ confirmed that ethylene glycol could significantly improve the stability of $\mathrm{H}_{2} \mathrm{O}_{2}$ in some applications. Mahajan and Misra [26] studied peroxide assisted sulphuric acid leaching $\left(\mathrm{H}_{2} \mathrm{SO}_{4}+\mathrm{H}_{2} \mathrm{O}_{2}\right)$ of copper from chalcopyrite mineral. The researchers tested the effect of ethylene glycol (1-8 $\mathrm{mL} / \mathrm{L}$ ) on consumption of $\mathrm{H}_{2} \mathrm{O}_{2}$ over a period of $4 \mathrm{~h}$. They found that, in the absence of glycol, almost complete decomposition of $\mathrm{H}_{2} \mathrm{O}_{2}$ was observed while addition of glycol substantially improved $\mathrm{H}_{2} \mathrm{O}_{2}$ stability i.e. $75 \%$ of $\mathrm{H}_{2} \mathrm{O}_{2}$ was still remained in leach solution in the presence of $8 \mathrm{~mL} / \mathrm{L}$ glycol. Bas et al. [14] studied the influence of ethylene glycol on treatment of X-ray film effluents (thiosulphate media) with $\mathrm{H}_{2} \mathrm{O}_{2}$ for recovery of silver. They showed that addition of glycol enhanced silver recovery by up to $18.7 \%$. They attributed this effect to the stabilisation of $\mathrm{H}_{2} \mathrm{O}_{2}$ by the addition of ethylene glycol.

The results (Figures 7-8, Table 1) implied that under aggresive conditions, ethylene glycol gave unsatisfactory results for the stabilisation of $\mathrm{H}_{2} \mathrm{O}_{2}$ presumably due to its extreme instability at high temperature and $\mathrm{pH}$.
Previous studies [7,16] also reported that high temperature and $\mathrm{pH}$ negatively influence the stability of hydrogen peroxide.

The findings in the current study demonstrated that ethylene glycol can be suitably used to improve the stability of $\mathrm{H}_{2} \mathrm{O}_{2}$ in the presence of copper particularly at low temperature and $\mathrm{pH}$. On the contrary, citric acid was found to facilitate decomposition of $\mathrm{H}_{2} \mathrm{O}_{2}$ in the presence of copper ( $5 \mathrm{~g} / \mathrm{L})$.

\section{References}

[1] Jones, C.W. 1999. Applications of Hydrogen Peroxide and Derivatives, Royal Society of Chemistry, UK, 274p.

[2] Habashi, F. 1999. Textbook of Hydrometallurgy, Metallurgie Extractive Quebec, 739 p.

[3] Marsden, J, House, I. 2006. The Chemistry of Gold Extraction. Society for Mining, Metallurgy, and Exploration, USA, 688 p.

[4] Gupta, C.K., Mukherjee, T.K. 1990. Hydrometallurgy in Extraction Processes Vol. I-II. CRC Press, Boston.

[5] Dreisinger, D. 2006. Copper Leaching from Primary Sulfides: Options for Biological and Chemical Extraction of Copper, Hydrometallurgy, Vol. 83, pp.1020.

[6] Baba, A.A., Ayinla, K.I., Adekola, F.A., Ghosh, M.K., Ayanda, O.S., Bale, R.B. 2012. A Review on Novel Techniques for Chalcopyrite Ore Processing. International Journal of Mining Engineering and Mineral Processing. Vol. 1, pp.1-16.

[7] Yazıcı, E.Y., Deveci, H. 2010. Factors Affecting Decomposition of Hydrogen Peroxide, XII International Mineral Processing Symposium (IMPS), 6-8 October, Cappdocia, Turkey, 609-616. 
[8] Deveci, H., Yazıcı, E.Y., Aydın, U., Yazıcı, R., Akçil, A.U.2010. Extraction of Copper from Scrap TV Boards by Sulphuric Acid Leaching Under Oxidising Conditions, Going Green-Care Innovation, 8-11 November, Vienna, Austria, Paper no: 045.

[9] Yazici, E.Y. 2012. Recovery of Metals from E-wastes by Physical and Hydrometallurgical Processes, Karadeniz Technical University, PhD Thesis, 210p. (in Turkish).

[10] Kamberović, Ž., Korać, M., Vračar, S., Ranitović, M. 2010. Preliminary Process Analysis and Development of Hydrometallurgical Process for the Recovery of Copper from Waste Printed Circuit Boards. Proceedings of Going Green-Care Innovation Conference, 8-11 November, Vienna, Austria.

[11] Evonik Industries. Hydrogen Peroxide Application Areas http://h2o2.evonik.com/product/ h2o2/en/applicationareas/pages/default.aspx [Accessed: 09.03.2017]

[12] Mudder, T.I., Botz, M.M. 2001. The Chemistry and Treatment of Cyanidation Wastes, Mining Journal Books Ltd., London, 393 p.

[13] Tuncuk, A., Stazi, V., Akcil, A., Yazici, E.Y., Deveci, H. 2012. Aqueous Metal Recovery Techniques from E-scrap: Hydrometallurgy in Recycling, Minerals Engineering, Vol. 25, pp.28-37.

[14] Bas, A.D., Yazici, E.Y., Deveci, H. 2012. Recovery of Silver from Xray Film Processing Effluents by Hydrogen Peroxide Treatment, Hydrometallurgy, Vol. 22, pp.121124.

[15] Evonik Industries. About Hydrogen Peroxide: Stability and Decomposition http://h2o2.evonik.com/product/ $\underline{\mathrm{h} 2 \mathrm{o} 2 / \mathrm{en} / \mathrm{about} \text {-hydrogen- }}$ peroxide/basic- information/stability-anddecomposition, [Accessed: 11.03.2017]

[16] Kim, E-H., Kim, Y-H., Chung, D-Y., Shin, Y-J., Yoo, J-H., Choi, C-S. 1996. Decomposition of Hydrogen Peroxide in the Aqueous Solution, J Korean Inst Chem Eng, Vol. 34, pp.249-252.

[17] Khalil, R.M. 1990. Kinetics of Decomposition of Hydrogen Peroxide over Different Electrodeposited Nickel Powder Catalysts, J of King Abdulaziz University, Vol. 2, pp.91-100.

[18] Kushibe, K. 1976. Method of Stabilizing Acid Aqueous Solutions of Hydrogen Peroxide, US Patent.

[19] Hopkins, Q.G., Browning, J.N. 1985. Stabilization of High Purity Hydrogen Peroxide, US Patent.

[20] Itani, K., Miyashiro, Y. 1992. Method for Stabilizing Acidic Aqueous Hydrogen Peroxide Solution Containing Copper, US Patent.

[21] Jeffery, G.H., Bassett, J., Mendham, J., Denney, R.C. 1989. Vogel's Textbook of Quantitative Chemical Analysis, John Wiley \& Sons Inc., New York, 980p.

[22] Illustrated Glossary of Organic Chemistry http://web.chem.ucla.edu/ hardi ng/IGOC/E/ethylene glycol.html20 17. [Accessed: 03.03.2016]

[23] Shabani, M.A., Irannajad, M., Azadmehr, A.R. 2012. Investigation on Leaching of Malachite by Citric Acid, International Journal of Minerals, Metallurgy, and Materials, Vol. 19, pp.782-786.

[24] Ergun, S. 1956. Application of Principle of Least Squares to Families of Straight Lines, Industrial \& Engineering Chemistry, Vol. 48, pp.2063-2068.

[25] Powell, N., Jordan, M.A. 1997. Batch Leaching Data Analysis: Eradication of Time Dependency 
Prior to Statistical Analysis, Minerals Engineering, Vol. 10, pp.859-870.

[26] Mahajan, V., Misra, M, Zhong, K., Fuerstenau, M.C. 2007. Enhanced Leaching of Copper from Chalcopyrite in Hydrogen Peroxide-Glycol System, Minerals Engineering, Vol. 20, pp.670-674.

[27] Demir, F., Laçin, O., Dönmez, B. 2006. Leaching Kinetics of Calcined Magnesite in Citric Acid Solutions, Industrial \& Engineering Chemistry Research, Vol. 45, pp.1307-1311.

[28] Hamada, Y.Z., Cox, R., Hamada, H. 2015. $\mathrm{Cu}^{2+-C i t r a t e}$ Dimer Complexes in Aqueous Solutions, Journal of Basic \& Applied Sciences, Vol. 11, pp.583-589.

[29] Apelblat, A. 2014. Citric Acid, Springer, Switzerland, 357p.

[30] Patnaik, P. 2004. Dean's Analytical Chemistry Handbook, McGraw Hill, USA, 1280p.

[31] Amer, S. 2012. Treating citratechelated metals, Pollution Engineering, pp.27-28.

[32] Habbache, N., Alane, N., Djerad, S., Tifouti, L. 2009. Leaching of Copper Oxide with Different Acid Solutions, Chemical Engineering Journal, Vol. 152, pp.503-508. 